\title{
An emerging diplomatic system for the EU? Frameworks and Issues
}

\author{
Brian Hocking and Michael Smith \\ Department of Politics, History and International Relations \\ Loughborough University, Loughborough, Leicester
}

Summary: I. Introduction. - II. Diplomacy: contexts of change.III. A changing diplomatic milieu and the EUDS. - IV. Diplomatic systems: from hierarchies to networks. $-\mathrm{V}$. Towards Multi-stakeholder Diplomacy. 1. Roles. 2. Locations. 3. Representation. 4. Rules.-VI. 'Network Diplomacy' and 'Multi-Stakeholder Diplomacy' in the EUDS.-VII. The Road to an EU Diplomacy. VIII. Conclusions.

Resumen: El presente artículo analiza la emergencia de lo que puede denominarse el «Sistema Diplomático» de la UE (SDUE). En primero lugar analiza la naturaleza cambiante de la diplomacia, identificando diversos problemas referidos a sus contornos, capacidad, y legitimidad, su dimensión multinivel y a la multiplicación de los actores. Tales serán los problemas a los que el medio diplomático europeo habrá de responder ante la emergencia del SDUE. Posteriormente el trabajo despliega un marco general para analizar tres áreas claves: en primer lugar, el desarrollo institucional de la diplomacia de la UE; en segundo lugar, la conducción estratégica de la diplomacia para el mejor posicionamiento global de la UE; y, en tercer lugar, el desarrollo de una diplomacia estructural, caracterizada por un compromiso con la construcción de la paz y las instituciones. El trabajo concluye con algunas prognosis sobre el SDUE tras el Tratado de Lisboa, e identifica algunos desafíos y oportunidades.

Palabras clave: UE, diplomacia, sistema diplomático, Tratado de Lisboa.

Abstract: This paper addresses the general problems encountered by EU's diplomacy, and specifically the emergence of the EU 'diplomatic system' (EUDS). First, the paper analyses the changing nature of diplomacy, identifying issues relating to boundaries, capacity and legitimacy and paying particular attention to multi-level and multistakeholder diplomacy. These are linked with consideration of the EU diplomatic milieu and the issues confronting the emergent EUDS. The discussion then deploys a general framework to consider three areas of diplomatic practice in the EU: first, the institutional development of EU diplomacy; second, the conduct of strategic diplomacy aimed at positioning the EU in the global arena; and third, the development of structural diplomacy which has led to EU engagement in peace-building and state-building. The conclusions review the prospects for the EU's diplomatic system after the Lisbon Treaty, and identify potential future challenges or opportunities in the world arena.

Keywords: EU, diplomacy, diplomatic system, Lisbon Treaty. 


\section{Introduction ${ }^{1}$}

The Lisbon Treaty and the initial steps towards the development of the External Action Service (EAS) pose interesting questions regarding both the general processes and structures of diplomacy in the rapidly changing environment of contemporary world politics. Often, however, these questions are seen as existing in parallel yet disconnected universes with little linkage between the general diplomatic milieu and its EU manifestations. One reason for this is obvious: the essence of contemporary diplomacy is inevitably associated with the state whilst the ambitions of an EU 'diplomatic system' (EUDS) are cast in terms of some form of post-state order - or at least one in which the traditional claims of national sovereignty and the practices associated with it are hugely moderated. Yet there is clear ambivalence here. Whilst the aspirations of an EUDS are frequently presented in terms of alternative diplomatic paradigms to that associated with state-based diplomatic practice, inevitably much of the discourse surrounding it is rooted in assumptions and modalities that are the product of centuries of evolutionary adaptation. Additionally, it has to be appreciated that the other two dominant 'diplomatic systems' with which the EU is connected - namely those maintained by national governments and the increasingly complex global diplomatic system of which they are a significant part - are themselves confronting major challenges. Against this background, the aim of the paper is to set the discussion regarding the present and future state of EU international policy management in the context of broader debates within national foreign ministries, international organisations and, significantly, a range of non-state entities increasingly involved in the shaping and delivery of international policy. Consequently, whilst we identify some of the concrete features of the developing EUDS, our primary goal is to set an investigative agenda rooted in the issues confronting the role and structures of contemporary diplomacy rather than to provide a detailed empirical study.

The first part of the paper reviews the literature on the changing nature of diplomacy, identifying issues relating to boundaries, capacity and legitimacy and paying particular attention to multi-level and multi-stakeholder diplomacy. These are linked with consideration of the EU diplomatic milieu and the issues confronting the emergent EUDS. The discussion then deploys this general framework to consider three areas of diplomatic practice in the EU: first, the institutional development of EU diplomacy; second, the conduct of strategic diplomacy aimed at positioning the EU in the global arena;

1 The research and preparation for this paper is supported by the European Union Jean Monnet Programme through the Multilateral Research Network 'The Diplomatic System of the European Union: Evolution, Change and Challenges' (http://dseu.lboro.ac.uk) 
third, the development of structural diplomacy which has led to EU engagement in peace-building and state-building. The conclusions review the prospects for the EU's diplomatic system after the Lisbon Treaty, and identify potential future challenges or opportunities in the world arena.

\section{Diplomacy: contexts of change}

Evaluating the character and role of diplomacy in a transformational world order presents a number of interrelated issues. Not the least of these is the continued centrality of its forms and functions in world politics contrasted with relative marginalisation as an area of academic enquiry in an age dominated by processes related to globalisation, regionalisation and global governance. This is largely explained by the images associated with diplomacy as a core institution of a system of sovereign states embracing a set of principles and working practices rooted in values embracing secrecy, hierarchy, a dissociation with domestic arenas, insulation from non-state actors and pursuit of national interests in an age where the overarching claims of global interests are asserted.

At the same time, however, the functions of communication and negotiation central to the processes of diplomacy have never been in greater demand, stimulated by increasingly complex agendas and diverse sites of diplomatic activity. This tension between the apparent marginalisation of diplomacy and its centrality in contemporary world politics has shadowed the narratives of change in the international order, paralleling the debate on the significance or otherwise of the state through differing explanatory 'waves' of globalisation theory. One result has been a renewed interest in the essence of diplomacy and an attempt to locate this outside the dominant assumptions that its association with the Westphalian order have created ${ }^{2}$.

Debating diplomacy in this broader context assumes particular significance in the European Union (EU). On the one hand, the nature of its internal processes in terms of their sheer density and boundary-transcending qualities suggests some form of 'post-diplomatic' order significantly different from the images conjured by traditional, state-based diplomacy reflecting a 'logic of appropriateness' defined by the institutional frameworks and practices of 'Westphalian' diplomacy ${ }^{3}$. Yet, on the other, both the processes

${ }^{2}$ See COOPER, A.F., HOCKING, B. and MALEY, W. (eds.), Global Governance and Diplomacy: Worlds Apart?, Palgrave Macmillan, Houndmills, 2008.

3 See BÁTORA, J., "Does the European Union transform the institution of diplomacy?" in Journal of European Public Policy, vol. 12 (1), 2005. 
and structures embraced by the EU in the projection of its international policy objectives draw on a diplomatic tradition whose recent past has been fashioned by the broader European historical experience and projected from it to a global level. Moreover, as is discussed below, the emerging EUDS is not only deeply embedded in the historical traditions framing the experience of its Member States, but is also partly constituted by the resources that their own national diplomatic systems provide. Against this background, it is not surprising that discussions of the present and future state of EU diplomacy and the forms through which it can and should be projected are often both unclear and contentious. In one sense this is to be expected in a global environment in which the shape of diplomacy is increasingly complex as many conventions and assumptions on which it is based are challenged in line with the changing patterns of world politics.

Consequently, any approach emphasising the 'stateness' of diplomacy immediately presents a challenge to our understanding of what constitutes contemporary diplomacy in general and in the EU context specifically. Hence Bruter's observation in the late 1990s that one of the issues confronting EU Commission delegations has been adapting to the demands of a 'stateless' diplomacy. ${ }^{4}$ Similarly, in terms of its operational forms, the concept of 'structural' diplomacy has been presented as marking out aspects of a distinctive EU diplomacy ${ }^{5}$. From these perspectives, the EU as a non-state entity can be seen as presenting an existential challenge to established notions of diplomacy. However, the EU shares the space occupied by the broader network of diplomatic structures and processes and is influenced significantly by the diplomatic systems of its own member states - which are, not surprisingly, often taken as models for the fashioning of the External Action Service (EAS). At the same time, these diplomatic systems are themselves adapting as fundamental principles and assumptions of Westphalian diplomacy are questioned and its institutions modified in the face of rapid and extensive change. In the light of this, as noted earlier, one aim of this paper is to place discussion of the emergent EUDS against this background of potential uniqueness on the one hand and, on the other, a broader environment in which the diplomatic forms and traditions with which it is often contrasted are themselves experiencing significant transformation.

${ }^{4}$ See BRUTER, M., "Diplomacy without a state: the external delegations of the European Commission" in Journal of European Public Policy, vol. 6(2), 1999.

5 On the notion of structural diplomacy see KEUKELEIRE, S., "The European Union as a Diplomatic Actor: Internal, Traditional and Structural Diplomacy" in Diplomacy and Statecraft, vol. 14 (3), 2004, pp. 31-56; and KEUKELEIRE, S. and MACNAUGHTAN, J., The Foreign Policy of the European Union, Palgrave Macmillan, Basingstoke, 2008. 


\section{A changing diplomatic milieu and the EUDS}

Historically, the functioning of the state system has been facilitated by two forms of interlinked 'diplomatic systems'. The first of these is the global diplomatic system (GDS) which has been portrayed as the "master institution' of the international system, constituting 'a common field of diplomatic action'6. Over time, this has become increasingly complex both in terms of the range of participants operating within it, the issues that it confronts and the patterns of interaction characterising its operations. The second form of diplomatic system are the national diplomatic systems (NDS) maintained by national governments as one of the essential means through which their international policies are effected. Traditionally, the NDS has acted as a memory bank for the storage of information, as a key resource through which information is gathered, analysed and disseminated and as a source of policy advice. Although its precise forms are more varied than is sometimes assumed, the core of the system has been the ministry of foreign affairs (MFA) and the network of missions operated through its diplomatic service. Each of these systems forms essential components of the other. Thus the NDS provides both key communication nodes with the GDS whilst the latter is partly constituted by personnel, roles and norms of behaviour associated with a transnational community of diplomats representative of their national governments. The emergent EUDS is located alongside and between these two diplomatic systems, sharing space whilst overlaying them in significant ways. Since the EU is a complex, multilayered polity wherein the boundaries of member state and EU collective diplomacy are, in many contexts, illdefined the forms and structures of the EUDS are likely to be hybrid. This is because they draw on a set of diplomatic functions that transcend the state and a set of structures capable of maintaining linkages with national diplomatic systems - both member state and third party - and the GDS of which both states and the EU itself are a constituent part.

Consequently, the EUDS shares the problems associated with the functioning and constitution of the GDS and NDS. It is not our aim here to rehearse these in any depth but simply to note their general character that can be summarised as boundary, capacity and legitimacy dilemmas. The first of these, boundary issues, reflect a growing erosion of the traditional distinction between the realm of the diplomatic and the political (a point considered later) and the public and the private spheres of activity. This has generated questions regarding the nature of diplomacy as an activity, its re-

${ }^{6}$ See STEINER, "Introduction" in The Times Survey of Foreign Ministries of the World, Times Books, London, 1982, p. 11. 
quirements for effective deployment, how it can and should be conducted and the range of participants engaging in it. One significant manifestation of this has been the growing emphasis on the centrality of public diplomacy whose logic rests on the implications flowing from the increasingly indistinct boundaries between international and domestic policy environments ${ }^{7}$.

Each of these boundary issues is significant for the EU in its international operations. Thus the question 'what - and who - is a diplomat?' voiced with increasing frequency in recent years, has a particular resonance in the EU context. The historical development of the EUDS has in effect created several classes of 'quasi-diplomats' operating within a highly structured system in which external representation and communication have become central features ${ }^{8}$. In addition to national diplomats pursuing their tasks within and in relation to the EU institutions, there is the long-standing group of external relations specialists operating from the European Commission, and in some areas such as trade executing policy on the basis of extensive 'state functions' that have been allocated to the EU (and more specifically up to 2010, the European Community). But the Commission also contains a range of other external relations 'agents', operating in environments of more or less mixed competence with national diplomats - and of course, also operating increasingly within global governance institutions. Such a situation is characteristic for example of negotiations on climate change and broader international environmental issues 9 . Alongside this, the EU (and up to now, more specifically the European Commission) has developed a growing network of external representations and delegations, largely dedicated to commercial and related issues but increasingly drawn into areas such as human rights, good governance and other areas in which 'conditionality' has been exercised or attempted. Outside the realm of Commission-centred representation, there has also grown up a network of specialists and special representatives emanating from the Council of Ministers and coordinated by the High Representative for Foreign and Security Policy - for example, focused on EU policy coordination in the Middle East or sub-Saharan Africa. Without pursuing the matter further at this point, it seems clear that - perhaps to a unique extent - the boundaries of the EUDS have been shifting and expanding constantly over at least the past two decades.

7 See MELISSEN, J. (ed.), The New Public Diplomacy: soft power in international relations, Palgrave, Basingstoke, 2005.

${ }^{8}$ See SPENCE, D., "Taking Stock: Fifty Years of European Diplomacy" in The Hague Journal of Diplomacy, vol. 4(2), 2009, pp. 235-259.

9 See VOGLER, J., "The Challenge of the Environment, Energy and Climate Change" in HILL, C. and SMITH, M. (eds.), International Relations and the European Union, $2^{\text {nd }}$ edition, Oxford University Press, Oxford, 2011, forthcoming. 
Capacity issues are underpinned by the demands of complex transboundary agendas and the ability of diplomatic structures and processes to cope with them effectively. At the NDS level this has resulted in ongoing debates as to its composition and the degree to which this needs to move beyond its equation with the MFA. This is reinforced by changing emphases in the content of the diplomatic agenda and the response of the state to them. Hence the emergence of what has been termed the 'new regulatory state' is accompanied by a diffusion of diplomatic activity amongst a range of domestic and international agencies and groups, thereby reconstituting the NDS and decentring it from the MFA ${ }^{10}$. But it is not only the state whose capacity is questioned. Rather, all actors increasingly confront twin autonomy and resource dilemmas which demand that they engage with others in the development and delivery of international policy objectives. As a result, diplomacy can be reinterpreted outside the state-centred script of traditional diplomacy and viewed as a 'catalytic' activity in which coalitions of actors engage, exchanging resources whilst seeking to maintain their own identities ${ }^{11}$.

In this context, the EUDS has experienced a series of challenges reflecting in part the fluidity of boundaries noted above. The first of these is legal and institutional: given the EU's status as a 'community of law', it has always placed a great stress on the existence of a solid legal and institutional base for the development of policy and activity. But the EUDS in its constant state of flux and expansion has constantly tested the boundaries of this legal and institutional base. Seen from another perspective, the need for adaptation of diplomatic strategies and actions in the face of world events and the demand for EU activity has posed the constant possibility of 'extra-legal' or ad hoc responses that then create the possibility of legal and institutional challenge. Alongside this legal and institutional aspect, the changing nature of the EUDS has created a diffusion of agency in the international relations of the EU and thus a problem - part administrative, part political of defining the resources available and necessary to the pursuit of key 'European' tasks. The net result of this set of tensions has been a series of disputes - not entirely resolved by treaty revisions - about the nature, extent and location of the capacity to underpin the EUDS.

Legitimacy issues derive from a longstanding tension concerning the activities associated with the practice of diplomacy which are frequently manifest in both 'sending' and 'receiving' states. At home, the role of the

10 See JAYASURIYA, K., "Breaking the 'Westphalian' frame: regulatory state, fragmentation and diplomacy" in ROBERTSON, J. and EAST, M. (eds.), Diplomacy and Developing Nations: post-Cold War foreign policy-making structures and processes, Routledge, London, 2005.

${ }_{11}$ See HOCKING, B., "Catalytic diplomacy: Beyond "newness" and 'decline" " in MELISSEN. J., (ed.), Innovation in Diplomatic Practice, Macmillan, London, 1999. 
diplomat, the credentials of the diplomatic community and the values often associated with diplomacy are increasingly questioned. At the same time, the legitimacy of diplomatic activity in host states has always been a matter open to suspicion and has become more so as the emphasis on public diplomacy demands that diplomats engage with domestic interests in foreign countries. The EUDS shares these challenges but in a specific context. Thus whilst at one level it attempts to transcend aspects of state-centred diplomatic traditions and practice, it also seeks legitimacy for its place in the GDS by replicating key features of the NDS, as reflected in significant aspects of the emergent EAS. The very term, External Action Service, reflects the sensitivities surrounding the aspirations of the EU as a fully-fledged diplomatic actor alongside traditional national representative structures.

More specifically, a feature of the legitimacy problem has been the perennial question "who speaks for Europe?' ${ }^{2}$; this is not only a technical question but also one of the highest political significance. Leaving aside Henry Kissinger's (possibly apocryphal) demand to know what the telephone number for Europe might be, it is clear that the EUDS has come to display the features of a multiple advocacy and multi-level system of representation and communication. In doing so it might be reflective of the growth of such systems in diplomacy more broadly; but in the case of the EUDS, there are historically and institutionally rooted features that seem to mark it out. The multiple systems of representation noted above are linked to multiple diplomatic cultures, which have come to live in any uneasy coexistence but which might be very difficult to fuse into something approaching a common EU voice. Indeed, the proposal to constitute the European External Action Service from a mixture of Commission and Council officials, along with members of national diplomatic services, and to do so on the basis of an inter-institutional agreement between not only the Commission and the Council but also the European Parliament, can be seen as a heroic effort to create legitimacy at least in terms of the EU's institutional arrangements ${ }^{13}$. Whether it can create the kind of broader legitimacy that is at least in principle attached to national diplomatic systems is another question completely.

Understanding the environment in which the EUDS has to fashion its institutions and strategies therefore requires us to understand how these are

12 See, for instance, ALLEN, D., "Who Speaks for Europe? The Search for an Effective and Coherent External Policy" in PETERSON, J. and SJURSEN, H. (eds.), A Common Foreign Policy for Europe? Competing Visions of the CFSP, Routledge, London, 1998.

13 See DUKE, S., "Providing for European-Level Diplomacy After Lisbon: The Case of the European External Action Service" in The Hague Journal of Diplomacy 4(2): 211-33; and DUKE, S., The European External Action Service. Policy Paper 2, Jean Monnet Multilateral Research Network on the Diplomatic System of the EU, 2010, available at http://dseu.lboro.ac.uk. 
changing in the broader context of multilateral, plurilateral and national diplomatic practice. Here, the combined impact of boundary, capacity and legitimacy dilemmas has resulted in two linked trends: a growing emphasis on the transition from hierarchies to networks and, second, emergent forms of 'multistakeholder' diplomacy.

\section{Diplomatic systems: from hierarchies to networks}

In the light of the trends discussed above, it is unsurprising that network imagery has come to be applied to diplomacy and negotiation, drawing distinctions with the hierarchical principles underpinning traditional conceptions of diplomacy. Discussions of policy networks are replete with warnings regarding the ambiguity that surrounds the term and whether it represents a 'model' or a 'metaphor' ${ }^{14}$ Moreover, the literature is characterised by a growing typology of network structures such as 'advocacy coalitions', 'discourse coalitions' as well as 'epistemic communities', a manifestation of the phenomenon more familiar to students of international relations ${ }^{15}$. But underpinning these various conceptions is the proposition that networks are indispensable in managing increasingly complex international and domestic policy environments ${ }^{16}$. Whilst hierarchies emphasise formal, bureaucratic structures exemplified in national diplomatic systems, networks stress the need for states to develop the capacity to engage with an increasingly diverse range of institutions and actors ${ }^{17}$.

This is the fundamental principle on which the concept of global public policy networks rests ${ }^{18}$. Starting from the premise that globalization has highlighted the deficiencies of governments, both acting alone or in concert, in terms of their scope of activity, speed of response to global issues and range of contacts, it argues for the significance of emergence of net-

14 See PFETSCH, F., "Negotiating the European Union: a negotiation-network approach" in International Negotiation, vol. 3 (3), 1998, pp. 293-317; and more recently JUNG, T., "Policy networks: theory and practice" in OSBORNE, S., The New Public Governance?, Routledge, London, 2010.

15 See various contributions in Public Administration, special issue; "Comparing networks", vol. 76 (2), 1998.

16 See SLAUGHTER, A-M., A new world order, Princeton, Princeton University Press, 2004.

17 See ROBINSON, M., "Hybrid states: globalisation and the politics of state capacity" in Political Studies, vol. 56, 2008, pp. 567; and MOYNIHAN, D., "Combining structural forms in the search for policy tools: incident command systems in US crisis management" in Governance, vol. 21 (2), 2008, pp. 205-229.

18 See REINECKE, W., Global public policy: governing without government?, Brookings, Washington DC, 2000. 
works incorporating both public and private sector actors. It is not that multigovernmental institutions are irrelevant but that the more diverse membership and non-hierarchical qualities of public policy networks promote collaboration and learning and speeds up the acquisition and processing of knowledge. 'Vertical' subsidiarity in which policy making is delegated within public sector agencies, has to be supplemented by 'horizontal' subsidiarity through outsourcing to non-state actors. Underpinning the argument is the recognition of the value of division of labour between actors in specific policy settings and the advantages inherent in their respective qualities. If governments are not helpless pawns, neither are they dominant. NGOs, for their part, need openings to diplomatic networks, both bilateral and multilateral, if they are to maximise their influence over internationalised environments such as the EU. This creates a more subtle and nuanced pattern of relationships between state and non-state actors than the conflict stereotype which is frequently suggested. Esty and Geradin, in discussing the most effective form of regulatory system, argue that this is provided by what they term 'co-opetition' - a mix of co-operation and competition both within and across governments and between government and nongovernmental actors ${ }^{19}$.

A major factor likely to be influential here is the character of the diplomatic site as illustrated in the fourfold typology provided by Coleman and Perl: intergovernmental; multilevel governance, private regimes and 'loose couplings' 20 . One of the differentiating features of these sites is the degree of governmental presence, from high in the case of intergovernmental sites to low in the case of private, self-regulatory regimes and loose couplings, where interactions between transnational and governmental actors will tend to be relatively sparse and unstructured. The 'loose couplings' end of the Coleman and Perl network spectrum provides an increasingly rich yet, in traditional diplomatic imagery, unconventional field of activity. Often, the form of network resembles an 'issue network', based more on a mutual interest in pooling knowledge and ideas rather than a highly developed sense of shared values. Moreover, each is characterised by a varying degree of co-opetition between actors which confers on it significant elements of fragility and uncertainty. It is often noted that such networks, whilst they are differentiated from hierarchical structures in the sense that they are based on vertical organisational principles, are not hierarchy-free. Some actors are likely to be critical nodes in the network, or 'linking-pin organizations'

19 See ESTY, D. and GERADIN, D., "Regulatory Co-opetition" in Journal of International Economic Law, vol.3 (2), 2000, pp. 235-255.

${ }^{20}$ See COLEMAN, R. and PERL, A., "Internationalized policy environments and policy network analysis" in Political Studies, vol. 47 (4), 1999, pp. 701-707. 
which '... are able to control communication channels between actors that are unable to communicate directly'21.

\section{Towards multistakeholder diplomacy}

The need to operate within networked environments and the kinds of adaptation that this demands of the structures and processes of diplomacy has resulted in a growing emphasis on the emergence of 'multistakeholder' diplomatic processes. These processes not only bring together state and nonstate actors in both bilateral and multilateral diplomatic processes but, furthermore, pose a challenge to the principles on which state-based diplomacy is constructed. The concept of the 'stakeholder' has spread from the world of business to diplomatic practice partly through UN diplomacy such as the 1992 Rio Environmental Summit and, more recently, the World Summit on the Information Society (WSIS). ${ }^{22}$ Here, the Working Group on Internet Governance provides an environment for equal participation by the various stakeholders, government, business and civil society. ${ }^{23}$ Such a development clearly poses major challenges for many working principles on which traditional diplomatic processes rest. This applies to all forms of diplomatic system. As Ruggie has suggested, this can be seen in a clash of diplomatic cultures within the UN in response to criticisms of its humanitarian operations. On the one hand, a traditionalist diplomatic culture sees UN multilateral diplomacy focused on member states, shrouded in relative secrecy and with minimal accountability. Alongside this exists a 'modernist culture' rooted in transparency, and engagement with a wide range of internal and external stakeholders. The traditionalists, he argues, regard opaqueness and exclusiveness as a strategic asset whilst for modernists transparency is the key to institutional success (Ruggie 2005) ${ }^{24}$. In short, it is not only issues of partic-

${ }^{21}$ See JÖNSSON, C. et al., "Negotiations in networks in the European Union" in International Negotiation, vol. 3 (3), 1998, p. 328.

22 See WEISS, T. and GORDENKER, L. (eds.), NGOs, the UN and Global Governance, Lynne Rienner, Boulder, COL, 1996; O’BRIEN, R.A., GOETZ, M., SCHOLTE, J.A. and WILLIAMS, M., Contesting global governance: multilateral economic institutions and global social movements, Cambridge University Press, Cambridge, 2000; and FORMAN, S. and SEGAAR, D., "New coalitions for global governance: the changing dynamics of multilateralism" in Global Governance vol. 12, 2006, pp. 205-225.

${ }^{23}$ See DUMITRIU, P., "The World Summit on the Information Society (WSIS): from Geneva (2003) to Tunis (2005). A diplomatic perspective" in KURBALIJA, J. and KATRANDJIEV, V. (eds.), Multistakeholder Diplomacy: Challenges and Opportunities, DiploFoundation, Malta and Geneva, 2006.

${ }^{24}$ See RUGGIE, J., "Modernists must take over the United Nations" in Financial Times (24 January 2005). 
ipation which are involved, but the norms and rules determining the extent and nature of this participation.

\section{Roles}

Multistakeholder diplomacy (MSD), by definition, poses very different characteristics as can be seen from definitions to be found in the literature describing multistakeholder processes based on inclusiveness and partnership rather than on exclusiveness. Such processes aim to bring together all major stakeholders in a new form of common decision-finding (and possibly decision-making) on a particular issue. Furthermore, they assert that 'influence and the right to be heard should be based on the value of each stakeholders' unique perspective and expertise'25. This modifies the dominant diplomatic paradigm in significant ways. Not only does it challenge the 'club' model of diplomacy with its relatively closed, hierarchical characteristics, it offers a very different picture of who is involved (Hocking $2004)^{26}$. Thus the image of diplomacy provided by MSD is one in which non-state actors necessarily play a significant role.

By implication, whereas in the statist diplomatic model non-state actors are largely viewed as consumers of diplomacy, in the MSD model they may perform a more proactive role in terms of producers of diplomatic outcomes. However, these roles are likely to depend on the dynamics underpinning the trisectoral interactions between governments, NGOs and business. As Teegen and Dohhave suggested, the patterns of relationships between business and NGOs exist on a spectrum between what they term "stakegiver" roles in which positive outcomes are produced to 'staketaker' roles in which NGOs become opponents of the interests of other parties ${ }^{27}$.

It should be stressed, however, that the MSD model does not necessarily imply a diminished role for the professional diplomat. Indeed, that role might be enhanced but, at the same time, redefined. Rather than that of gatekeeper, the diplomat becomes what might be termed a boundary-spanner, recognising that boundaries between organisations, far from being irrelevant, are fluid and continually reconstitute themselves, becoming sites of intense activity ${ }^{28}$.

25 See HEMMATI, M., Multi-stakeholder Processes for Governance and Sustainability: beyond deadlock and conflict, Earthscan, London, 2002, p. 7.

${ }^{26}$ See HOCKING, B., "Changing the terms of trade policy making: from the 'club' to the multistakeholder model" in World Trade Review, vol. 3(1), 2004.

27 See DOH, J. and TEEGEN, H., Globalization and NGOs: transforming business, government and society, CT, Westport, 2003, pp. 204-206.

28 See ANSELL, C. and WEBER, S., "Organizing international politics: sovereignty and open systems" in International Political Science Review vol. 20 (1), 1999, pp. 73-94. 
In such an environment, actors - such as diplomats - able to assume the role of mediators or brokers, acquire a special significance. But their role takes on different forms encapsulated in terms such as that of facilitator and entrepreneur. Indeed, Rosenau sees a crucial role for diplomats in assisting the creation and legitimisation of new patterns of social contract between individuals and a plethora of spheres of authority ${ }^{29}$.

\section{Locations}

Part of the logic underpinning MSD is the redefinition of the sites within which diplomatic activity occurs. One of the most quoted writers on - and practitioners of - diplomacy, Harold Nicolson stressed two aspects of diplomacy, which he deemed significant to its successful operation: the first is the separation of policy formulation from its execution - the latter being the rightful province of diplomacy. The second is the separation of foreign and domestic policy ${ }^{30}$. It is arguable to what extent the 'old' diplomacy maintained these separations but it is undoubtedly the case that they are no longer features of the diplomatic environment - and certainly not in the EU context. The underlying rationale of MSD implies a mode of democratisation of diplomacy that renders both assumptions redundant in the contemporary negotiating environment. Moreover, the character of the stakeholders - particularly NGOs which operate in domestic and international environments simultaneously - means that the precise location of diplomacy becomes harder to determine. Thus one effect of MSD is to project the domestic environment more definitely into the international environment. But as noted earlier, the MSD model is likely to embrace a more diverse range of diplomatic sites reflecting a varying degree of governmental involvement.

\section{Representation}

Diplomatic systems are marked by two basic modes of representation: through missions and by means of permanent representation. The recent history in the evolution of state-centred diplomacy has emphasised the importance of mission over permanent bilateral diplomacy, reflecting the growing complexity and the technical nature of negotiations in, for example, the trade, arms control and environmental spheres. Here, there

29 See ROSENAU, J., "States, sovereignty and diplomacy in the information age", Virtual Diplomacy Series no. 5, United States Institute of Peace, Washington DC, 2000, pp. 12-13.

30 See NICOLSON, H., Diplomacy, Thornton Butterworth, London, 1939. 
is a direct linkage to MSD since one of the central impulses underlying it is to bring expertise lying outside government to areas of complex negotiations. But as we have seen above, the world of state-centred diplomacy has had to adjust to changes whose roots lie on the political and economic configuration of the international order as well as its social underpinnings. National diplomatic systems around the world confront, to a greater or lesser extent, similar problems: how to bear the burden of greater demands with fewer resources whilst responding to the internal challenges emanating form the claims of 'domestic' sectoral departments to act as their own representatives in international environments.

The concept of MSD adds another layer to the dilemmas of representation. ${ }^{31}$ Alongside statecraft is to be found what Cooper terms 'society-craft' or the weaving together of governmental diplomatic resources with those of non-state entities. ${ }^{32}$ This poses challenges to actors in diplomatic milieus in deciding with whom to engage in projecting their interests in regional and global environments and on what terms. Here, of course, engagement with stakeholders is not a new idea - the International Labour Organization is commonly regarded as one of the earliest instances, establishing in 1919 trisectoral representation from governments, unions and employers. But since the creation of the UN, the trend has grown apace with many of the concepts relating to stakeholder activity deriving from the Rio Earth Summit of 1992. As Dodds notes, a significant aspect of the subsequent Agenda 21 was its status as 'the first UN document to recognise the roles and responsibilities of nine stakeholder groups' ${ }^{33}$. Since then, the creation of the UN Commission on Sustainable Development has seen a gradual expansion of stakeholder engagement. But the intersection of the two diplomatic cultures creates tensions, underscoring the significant degree of control that statebased diplomacy exercises over access to the diplomatic environment. This is evident when comparing the development of stakeholder engagement in the UN system with that of the World Trade Organisation where the dominance of sovereignty-related rules provides a less congenial environment for the development of $\mathrm{MSD}^{34}$.

31 See LANGHORNE, R., "The Diplomacy of Non-State Actors" in Diplomacy \& Statecraft, vol. 16, n 2, 2005, pp. 331-339.

32 See COOPER, A.F., Test of Global Governance: Canadian Diplomacy and United Nations World Conferences, United Nations University Press, Tokyo, 2004.

${ }^{33}$ See DODDS, F., "The context: multistakeholder processes and global governance" in HEMMATI, M. Multi-stakeholder Processes for Governance and Sustainability: beyond deadlock and conflict, Earthscan, London, 2002. pp. 28-29.

${ }^{34}$ Cfr. MARCEAU, G. and PEDERSEN, P., "Is the WTO open and transparent? A discussion of the relationship of the WTO with non-governmental organisations and civil society's claims for more transparency and public participation" in Journal of World Trade, vol. 33(1), 1999. 


\section{Rules}

The transformation of diplomacy emphasises the tensions that underlie its operation in contemporary world politics and generates the frustrations frequently expressed by stakeholders of all types with multistakeholder processes. At the more general level, this reflects growing tensions between the norms governing international relations - as enshrined in the UN Charter and the 1961 Vienna Convention on Diplomatic Relations ${ }^{35}$. For example, Article 41 of the Convention requires diplomats not to interfere in the internal affairs of host countries, a requirement that clashes with the logic underpinning the current emphasis on public diplomacy strategies, which demand the development and management of relationships with foreign NSAs.

Consequently, if we are witnessing the emergence of a new phase in the evolution of diplomacy, of which the EUDS might be one manifestation, a key aspect is the development of norms and rules through which the emergent processes can function. Viewing the diplomatic landscape from an NGO perspective, Dodds suggests the need for the development of agreed norms and standards by which multistakeholder processes can operate. 'This will require a clearer definition of the role and responsibility of governments, as well as of stakeholders, and an agreement on the modes of interaction' ${ }^{36}$. The problem is that there are two sets of norms which are frequently in tension with one another in the MSD environment as behavioural expectations derived from sovereignty-related rules clash with non-sovereignty related norms of behaviour. To take one example, this can lead to differing approaches towards the values attached by stakeholders to confidentiality in negotiations as opposed to openness, accountability and transparency.

The character of these problems depends on the nature of the political environment, but in general they can be identified in terms of institutional tensions created by attempts to graft newer onto older modes of diplomacy; a 'crisis of expectations' which results from a mismatch of goals and ambitions on the part of the participants in the various processes, and a more general legitimacy debate which is nested in the broader debate about the nature of democratic processes in the face of globalization. The institutional tensions can be clearly seen in the trade policy sphere where conflicts produced by the definition of new rules at both the national and multilateral

35 See HALL, I., "The transformation of diplomacy: mysteries, insurgencies and public relations" in International Affairs, vol. 86 (1), 2010, pp. 247-256; and MARTIN, M., An Alternative to Statecraft: a Human Security Proposal for a European External Action Service, International Policy Analysis, Friedrich Ebert Stiftung, Bonn/Berlin, 2009.

${ }^{36}$ See DODDS, F., "The context: multistakeholder processes and global governance", op. cit., p. 37. 
levels are clearly evident. In terms of national processes of trade consultation the shift from a relatively closed 'club' to a more open multistakeholder model has generated tensions between business and NGOs with the former sometimes resenting what it regards as the incursion of the latter ${ }^{37}$.

Much of the disquiet, of course, reflects differing views as to the objectives of consultations, their structure and intended outcomes. And, equally obviously, this phenomenon is part of the stresses that are more generally manifest in the conduct of international policy making and diplomacy as NGOs, the business community government officials and representatives of a diverse range of international organisations find themselves rubbing shoulders with increasing frequency. It is hardly surprising that in areas such as trade and environmental policy, differing operational styles, organisational characteristics and, simply, a lack of familiarity between differing categories of participants, condition the workings of consultative processes. The case of trade policy provides a particularly interesting example of NSA participation since it has evolved through phases where it was traditionally formulated on businessbased consultative processes to current structures embracing both business and civil society. The resultant tensions can be seen in the case of the EU DG Trade Civil Society Dialogues where, as one commentator has noted, they "make it difficult for the creation of consultation spaces where the actors feel comfortable and, sometimes, frustrations and misunderstandings arise" 38 .

\section{VI. 'Network Diplomacy' and 'Multi-Stakeholder Diplomacy' in the EUDS}

The challenges presented to diplomatic structures and processes by the need to operate within networked, multistakeholder environments raises the familiar issues of policy coherence, reflected at national level in the quest for 'whole of government' approaches to the conduct of international policy. At the EU level, this concern has been widely identified and analysed. ${ }^{39}$

${ }^{37}$ See HOCKING, B., "Changing the terms of trade policy making: from the 'club' to the multistakeholder model", op. cit.

38 See MUGURUZA, M.I. "Civil society and trade diplomacy in the 'global age'. The European case: trade policy dialogue between civil society and the European Commission". Document for the Fourth Meeting of the Trade and Integration Network, Inter-American Development Bank, Washington DC, (17-18 September 2002), p. 13.

${ }^{39}$ Cfr. NUTTALL, S. "Coherence and Consistency" in HILL, C. and SMITH, M. (eds.), International Relations and the European Union, Oxford University Press, Oxford, 2005, pp. 91-112; and GEBHARD, C., "Coherence" in HILL, C. and SMITH, M. (eds.), International Relations and the European Union, $2^{\text {nd }}$ edition, Oxford University Press, Oxford, 2011, forthcoming. 
The external actions of the EU, based as they are on a multi-institutional and densely structured system of governance at the European level, are inherently challenged by problems of vertical coherence (between the European level and other levels such as that of the member states) and horizontal coherence (between the different areas of policy, characterized by different institutional settlements and political dynamics, that constitute 'European' policy). And of course, as noted earlier, the absence of government means that there is no necessary final arbiter of policy choices or silencer of debates. This can be presented as an advantage - the generation of an essentially deliberative mode of policy development in which multiple voices can be heard and can influence the outcome - but it can also be presented as a handicap to the development of consistent and coordinated positions and actions, or as generating a gap between the self-presentation of the EU and its capacity to produce effective actions.

Overall, in terms of hierarchies and networks, it appears that the EUDS is based on a partly hierarchical and partly networked system, but one in which allocations of resources and responsibilities can be constantly challenged and debated. Not only this, but different EU institutions can call on connections with different elements of civil society to buttress their positions, and are more or less open to influence from business organizations, NGOs and others. To use the terms deployed earlier in this paper, there is a lot of potential for the kinds of 'loose couplings' that generate challenges of coordination and execution in the new diplomatic milieus characteristic of the twenty-first century. But in the EU case, there is an institutionalization of the hybrid forms of diplomatic pressure and activity that are seen by some as a feature of diplomacy at the global level. The ways in which these two levels of hybridity and complexity may interact are equally complex, and give rise to phenomena such as that of 'bimultilateral' negotiation or three-level negotiations, in which the basis for the negotiations themselves can be at issue within the EU at the same time as the EUDS is being used to pursue them at the international level ${ }^{40}$.

The arguments above lead to the conclusion that the EUDS is a case study in the effects of multi-stakeholder diplomacy, characterized by challenges of roles, location, representation and rules. There is hybridity of participation, accompanied by the pursuit of multiple interests and characterized by the indeterminacy of both processes and outcomes. This appears to be the case in (at least) two dimensions. First, the EUDS itself is a product of diplomatic activity and negotiation at several levels and in several of-

40 See SMITH, M., "The European Union and the United States: the Politics of 'Bi-Multilateral' Negotiation” in ElGSTRÖM, O. and JÖNSSON, C. (eds.), European Union Negotiations: Processes, Networks and Institutions, Routledge, London, 2005, pp. 164-182. 
ten interconnected arenas. Second, the EUDS - whilst experiencing the effects of this 'internal' complexity - is injected into an increasing range of international processes characterized by 'external' complexity of the kind discussed earlier in the paper. It would be easy at this point simply to throw up one's hands and conclude that it is all too complex to bother with - but that is in itself part of the point.

Faced with this multi-level and multi-stakeholder milieu, we need to develop at least some view on the ways in which at the level of the EUDS, it is made comprehensible and in which the search for mechanisms to ensure consistency and coherence takes place. Attention to roles thus tells us that the EUDS is likely to be used as the vehicle for development and projection of role-conceptions at the EU level, as well as for the performance of those roles and evaluation of the effectiveness with which the roles have been pursued ${ }^{41}$. It also tells us, however, that those roles may be contested both from within and outside the EUDS. Attention to the location of issues and participants, and to the erosion on the separations between different arenas and classes of actors, tells us that the EUDS should be approached in terms of the ways in which it either seeks to perpetuate 'traditional' locations of issues and authority or seeks to express the interconnectedness and fluidity of diplomatic issues in the current era. More likely than a finding one way or the other in this area is a finding that notes the uneasy coexistence of the separations and the interconnections. Attention to representation is likely to draw attention to the fact that the EUDS is in a sense trying to construct a 'European' diplomacy the wrong way round - to fashion a coherent and unified system of diplomatic representation where there are already several well established diplomatic or quasi-diplomatic entities in the field.

Finally, attention to rules is likely to alert us to a number of features relating to the normative basis of the EUDS and to some of the internal and external contradictions to which this might give rise. We are all familiar with the assertion that the EU is a 'normative power' and/or an 'ethical power' 42 , and also with the uneasy feeling that this (self)conception of the EU does not always work out when it is confronted with reality. In the case

${ }^{41}$ See ELGSTRÖM, O. and SMITH, M. (eds.), The European Union's Roles in International Politics: Concepts and Analysis, Routledge, London, 2006.

${ }^{42}$ Cfr. MANNERS, I., "Normative Power Europe: A Contradiction in Terms?" in Journal of Common Market Studies vol. 40(2), 2002, pp. 234-258; SJURSEN, H. (ed.), Civilian or Military Power? European Foreign Policy in Perspective, Routledge, London, 2009; AGGESTAM, L. (ed.), Ethical Power Europe?, Special Issue of International Affairs, vol. 84(1), 2001; and WHITMAN, R. (ed.), Normative Power Europe: Theoretical and Empirical Perspectives, Routledge, London, 2011. 
of the EUDS specifically, we are led to question the extent to which it can support a normative/ethical external policy, and thus indirectly to question the effects on the EU's diplomacy of fuller insertion into the global diplomatic system, as opposed to the rather marginal or differentiated ways in which the EU has been represented to date. We are also led to other questions relating to the EU's capacity to comply with or to (re)shape the rules of the global diplomatic system, which are fundamental to the Union's international role(s).

The discussion so far has tried to expose the kinds of questions that arise when the EUDS is subjected to examination in terms of the approaches to diplomacy set out earlier in the paper. As anticipated, there is a set of questions to which we have no answers, or at best partial answers and suggestions for further research. One question that has not so far been exposed, but which hovers over all that has been said above, is this: given that diplomacy has been in a process of at least partial transformation during (at least) the period since the end of the Cold War, what exactly is the potential role of the EU in its further evolution? Two possibilities stand out. First, the EUDS as developed over the past fifty years and further consolidated by the Lisbon Treaty has been part of that transformation and could be a potent agent of further transformation. Second, the EUDS is more likely to be transformed by than to transform the global diplomatic system as a consequence of its further incorporation into the existing structures. The reality is of course that there is likely to be an uneasy coexistence of these two sets of forces.

\section{The Road to an EU Diplomacy}

Taking as read the already noted fact that there is and has been for some time a functioning if partial EUDS ${ }^{43}$, the concern in this section of the paper is to identify some key areas in which we should look for problems or progress in the pursuit of an EU diplomacy and the development of the EUDS. Our baseline is the Lisbon Treaty, and the perception that this has laid the basis for a consolidated and well-founded EUDS centred on the strengthened position of the High Representative, the establishment of the EEAS and the provision of the broader institutional and material resources on which the EUDS can flourish and grow. We take three areas as our focus for brief evaluations: first, the institutional debate; second, the pursuit of strategic diplomacy; third, the practice of structural diplomacy.

${ }^{43}$ See SPENCE, D., "Taking Stock: Fifty Years of European Diplomacy”, op. cit. 
First, the institutional debate. The Lisbon Treaty did not settle the form and content of the EEAS, or indeed the role of the HR. Rather, it set an agenda for further debate and for some very hard bargaining, as well as leaving unclear the respective positions and claims of three 'presidential' contestants: the respective presidents of the Commission, the European Council and the Council of Ministers. Not only this, but it gave the EP a strong basis for claiming additional control over the EUDS, especially through the budgetary system but also through the extension of its power of assent over international agreements. The result of these conflicting claims has been a continuing debate (if that is not too mild a word) over the 'ownership' of the EEAS and of assets central to the EUDS, such as overseas delegations - a debate that was eminently predictable and indeed predicted ${ }^{44}$. It appears that the EUDS is itself a stake in a contest for influence within and between the European institutions, and that this will affect the detailed arrangements for its consolidation and its operations. Another feature of the debate has been its (relatively) closed nature: this is indeed a debate within and between the Brussels institutions, into which only the voice of the EP injects an element of civil society (and the extent to which the EP can be seen as representative here is also open to question). The current position suggests that if one conceives of the EUDS as part of a negotiated order at the European level ${ }^{45}$, the negotiation is more about inter-institutional bargaining than it is about negotiation and problem-solving - and that this is likely to affect the ability of the EEAS, when it finally swings into full action in December 2010, to establish its autonomy from continuing inter-institutional contestation. It also raises important questions about a number of the issues raised earlier in this paper, especially those of boundaries, capacity and legitimacy, and suggests that these will be a continuing concern.

Second, the issue of strategic diplomacy. For some, this might seem to be a contradiction in terms, but it has real importance in the EU context. The EU has been a prolific creator of strategies for its external relations, with a number of core aims: reflecting the internal integration process, positioning itself in the global arena, managing its relations with key international partners or rivals and in key sectors of international governance (Allen and Smith 2009). These strategies themselves are in a sense a product of diplomacy, since they embody the fruits of an internal negotiation with

${ }^{44}$ See DUKE, S., "Providing for European-Level Diplomacy After Lisbon: The Case of the European External Action Service", op. cit. and DUKE, S., The European External Action Service, op. cit.,

45 See ELGSTRÖM, O. and SMITH, M. (eds.) "Introduction: Negotiation and PolicyMaking in the European Union - Processes, System and Order" in Journal of European Public Policy, vol. 7(5), 2000, pp. 673-83. 
a quasi-diplomatic tinge to it. They also carry with them major implications for the direction and character of subsequent EU diplomacy, since they embody a set of principles and a set of strategic targets towards which that diplomacy should be directed - although it can be and has been questioned whether they constitute a 'grand strategy' in the sense that this term has been applied for example to US foreign policy ${ }^{46}$. The EU is not alone in pursuing this kind of programmatic approach to diplomatic action, but it has taken a more wide-ranging and comprehensive approach than other international actors (perhaps reflecting the issues of coherence and consistency noted earlier in this paper). But it is not always clear what the detailed implications of these strategies are for diplomacy in the field -especially when the strategy is confronted by awkward realities, as has been the case for example in EU-China relations ${ }^{47}$. One question that inexorably arises from such a potential 'gap' between strategy and diplomacy is about the authority to adapt, to reconcile and to renew the diplomatic 'line' - where does this lie in the structure of competing institutional and other interests noted above? There are important further implications here for the interaction of stakeholders both within and around the EUDS, and for the tensions between hierarchy and networks that were discussed earlier.

Finally, let us turn to the practices of structural diplomacy. As Stephan Keukeleire and his colleagues have pointed out, there has been a shift in the objective of diplomacy since the end of the Cold War towards the attempt to shape the structures, rules and processes by which actors related to each other on the global arena, and (as a reflection of this) towards shaping what might previously have been seen as essentially 'domestic' structures of governance and order in national societies ${ }^{48}$. In this way, 'structural diplomacy' has an essentially transgressive nature, challenging as it does some of the traditional 'separations' pointed out earlier in this paper. Importantly, the EU has been an active - if not the leading - practitioner of such structural

${ }^{46}$ Cfr. COWARD, M., "International relations in the post-globalisation era" in Politics vol. 26(1), 2006; BISCOP, S., HOWORTH, J. and GIGERICH, B., Europe: A Time for Strategy, Egmont Paper 27, Royal Institute for International Relations, Brussels, 2009; DE VASCONCELOS, A. (ed.), A Strategy for EU Foreign Policy. Report No. 7, EU Institute for Security Studies, Paris, 2010; HOWORTH, J., "The EU as a Global Actor: Grand Strategy for a Global Grand Bargain?" in Journal of Common Market Studies vol. 48(3), 2010, pp. 455-474.

47 See SMITH, M. and XIE, H., "The European Union and 'Strategic Partnership' with China: How Much Strategy? How Much Partnership?", Paper presented to the UACES Annual/Research Conference, Angers, France, September, 2009.

48 See KEUKELEIRE, S., "The European Union as a Diplomatic Actor: Internal, Traditional and Structural Diplomacy”, op. cit.; KEUKELEIRE, S. and MACNAUGHTAN, J., The Foreign Policy of the European Union, op. cit.; and KEUKELEIRE, S., THIERS, R. and JUSTAERT, A., "Reappraising Diplomacy: Structural Diplomacy and the Case of the European Union" in The Hague Journal of Diplomacy, vol. 4(2), pp. 2009, pp. 143-65. 
diplomacy, most obviously through its enlargement processes and the European Neighbourhood Policy but also through its engagement in processes of post-conflict reconstruction and conflict prevention. It can readily be seen that this is strongly related to the (self)conception of the EU as a model of international order and as a normative or ethical power, as discussed earlier in the paper. The practice of structural diplomacy also embodies an assumption that the EU is well placed to pursue political and other forms of conditionality and (by implication) that the EU as a form of civilian power is able to contribute in ways that other powers are largely unable to reproduce. It might also be argued that given the ways in which structural diplomacy demands field coordination of EU institutions and assets, it is a good basis for the development of a post-Lisbon structural diplomacy based on the EEAS and on the coordinating role of the HR.

But there are important challenges to be faced. The first of these, as pointed out by Keukeleire and his colleagues ${ }^{49}$, is that the impact of structural diplomacy as practiced by the EU has suffered from severely diminishing returns, and that local resistance to EU initiatives has often disabled the broader political objectives of the diplomacy. The second - already noted in other contexts - is that the issues of coordination and the mobilization of resources are by no means settled, and that in some ways they need to be 'reinvented' for successive EU activities - especially where there are very long implementation chains and potential gaps between principals and agents. Finally, there is a problem inherent in the very transgressiveness of structural diplomacy - that it may be going beyond the boundaries of what is acceptable in the current global diplomatic system and thus creating risks for the perceived legitimacy of the EUDS both within and outside the EU.

Any overall evaluation of the prospects for the EUDS at his moment must necessarily be very provisional. Although the institutional settlement on which its further development will be based has been ratified but the translation of this settlement into habits of working together and learning together is a matter for the coming years. What we can say on the basis of this section of the paper is that there are several challenges to come. Some of these reflect the debate and the competition for authority within the EU, whilst others reflect the underlying challenges attached to the extension of modes of diplomacy which are themselves a major test of the EU's international legitimacy and ability to influence events. As noted above, however, the challenges do reflect strongly a number of the key developments in diplomacy more generally that we discussed in the early parts of this paper. This leads us to our conclusions.

49 Ibid. 


\section{Conclusions}

This paper has been more concerned to raise questions and suggest linkages than to attempt detailed empirical testing or the framing of definitive conclusions. It presents an agenda for research on the EUDS rather than the findings of research. But it does allow us to propose some interim conclusions that will guide further research in this area.

The first of these is that it is impossible - and unwise - to disconnect the development of the EUDS from the development of diplomacy more broadly defined in the post-Cold War era. The problems raised in the early parts of the paper about the changing milieu of diplomacy and changing practices of diplomats and others are strongly reflected in the recent and current development of the EUDS. Issues of boundaries, capacity and legitimacy are easy to identify - less easy to analyse and test. Questions of authority and interaction relating to hierarchies and networks are integral to our understanding of where the EUDS has come from and where it may be going. And the challenge of multi-stakeholder diplomacy in terms of roles, locations, representation and rules is equally discernible not only in the debates about the EUDS itself but also in the pursuit of strategic and structural diplomacy.

The second conclusion is that the distinctive history, institutional development and normative preoccupations of the EUDS can be seen both as assets and liabilities in the creation and pursuit of an EU diplomacy. As noted above, in a way the EU is trying to create a European diplomacy by incorporating (or deconstructing) a number of strands that have been in existence for some time and have their own distinctive trajectories and cultural predispositions. This is a big challenge at the micro-level, in terms of the development of the institutional settlement on the basis of which the EUDS will operate; it is also a big challenge at the macro-level, in terms of the ways in which the EUDS can either contribute to the (re)shaping of the global diplomatic system or be (re)shaped by that system. The challenge for those who will create the 'new' EUDS is immediate and imposing.

The third conclusion is that by extension the progress of the EUDS will depend, as do other areas of the EU's international relations, on the interaction of three logics. ${ }^{50}$ The first of these is the 'internal logic' - the ways in which the progress or problems of the internal integration process play into the development of policy, and in which the development of policy itself can be seen as a contribution to integration. The second is the 'external logic' - the existence of external challenges or opportunities that

50 See SMITH, M., "Between Soft Power and a Hard Place: European Union Foreign and Security Policy between the Islamic World and the United States" in International Politics vol. 46 (5), 2009, pp. 596-615. 
empower or dis-empower the EU in dealing with significant international issues or competitors. The third is the 'identity logic' - the ways in which the search for a European identity with its center of gravity in the EU has a shaping influence on the ways in which the EUDS is targeted and the ambitions it is asked to serve. In the context of the argument made in this paper, it can be seen that the 'internal logic' of argument about the institutional foundations of the EUDS has dominated during the past few months, for obvious reasons. But this does not mean that the 'external logic' is unimportant - indeed, it may be that the introspection caused by the focus on institutional arrangements has ruled the EU out of important processes in the broader global diplomatic system and increased the extent to which the EU might be seen as marginal to the great questions of the day. Nor does it mean that the 'identity logic' can be ignored: after all, the creation and activation of an EUDS in a new and more ambitious form is organically related to the idea that the EU can and should frame a new identity with which to address the world and its own citizens. Just at the moment, in mid-2010, it is difficult to be sanguine about the impact of these logics either separately or collectively, and the key question is whether the shaping of the EUDS will be disabled or given momentum by them. 